\title{
AN INTENSIONAL VIEW OF JUDGMENT IN KANT'S KRV
}

\author{
EVANDRO C. GODOY ${ }^{1}$ \\ https://orcid.org/0000-0003-0758-972X \\ IFSul, Campus Sapucaia do Sul \\ Sapucaia do Sul, R. S. \\ Brazil \\ evandrocgodoy@yahoo.com
}

\section{Article info}

CDD: 193

Received: 27.07.2020; Revised: 22.11.2020; Accepted: 23.11.2020

https://doi.org/10.1590/0100-6045.2021.V44N1.EG

\section{Keywords}

Kant

Transcendental Idealism

Logic

Synthetic and Analytic

\begin{abstract}
This paper presents an elucidation of Kant's notion of judgment, which clearly is a central challenge to the understanding of the Critic of Pure Reason, as well as of the Transcendental Idealism. In contrast to contemporary interpretation, but taking it as starting point, the following theses will be endorsed here: i) the synthesis of judgment expresses a conceptual relation understood as subordination in traditional Aristotelian logical scheme; ii) the logical form of judgment does not comprise intuitions (or singular representations); iii) the relation to intuition is not a judgment concern; iv) the response to the question about the ' $x$ ' that grounds the conceptual relation in judgments must be sought in transcendental aspects: 1) on construction in pure form of intuition, 2) in experience and 3) in the requirements to experience, respectively to mathematical, empirical, and philosophical
\end{abstract}

1 IFSUL - Instituto Federal de Educação, Ciência e Tecnologia Sul-rio-grandense / CNPq - Conselho Nacional de Desenvolvimento Científico e Tecnológico, Brazil. <evandrocgodoy@yahoo.com> 
judgments. The overall purpose is to build up an understanding of judgment that supports a latter assessment of Kant's theoretical philosophy.

The aim of this paper is to elucidate Kant's conception of judgment. A correct interpretation of the central proposal of the critical program, the enquiry concerning the possibility of synthetic a priori judgments, obviously depends on a correct interpretation of judgment, which in turn depends on determining how predication, and the logical subordination of the subject to the predicate, may (or must) be conceived. As these things are not quite clear in the Critique of Pure Reason ${ }^{2}$, it seems productive to search for more elements in the logical and historical contexts.

The contemporary interpretation tends to fluctuate between two approaches to judgment, one supported by a conception derived from analytic philosophy, and the other from Port-Royal Logic. The analytical interpretation supposes, implicitly or explicitly, that it is possible to read the 'function of unity among our representations' ( $\mathrm{KrV}, \mathrm{A} 69 / \mathrm{B} 94)$ as the subsumption of an object under a function, in FregeRussellian style 3 . On the other hand, the reading from PortRoyal adopts a historically more acceptable point of view, explaining judgment as predication in the scheme of Aristotelian logic, plus some novelties of modernity. The view from Port-Royal takes judgment as, or at least involves, the subordination of a singular under a universal representation ${ }^{4}$. Indeed, the dispute of the readings relies on

${ }^{2}$ Kritik der reinen $V$ ernunft, henceforth $\mathrm{KrV}$, quoted and referred to in its two editions, $\mathrm{A}$ and $\mathrm{B}$, as usual.

${ }^{3}$ See, for instance, Schulthess (1981) and Strawson (1999).

4 See Pariente (1985), Brandt (1995) and Longuenesse (2000). Hanna (2018) takes a position closer to this, with respect to the

Manuscrito - Rev. Int. Fil. Campinas, v. 44, n. 1, pp. 131-148, Jan.-Mar. 2021. 
the predicative relation established between a singular representation (an intuition) and a general representation (a concept) from an extensional perspective. This paper starts from a critique of these views and presents a reading of judgment as subordination only of general representations, based on exegetical and historical analysis, whence the prominence of the intensional aspect imposes itself.

The analytical interpretation offers a view of subordination in conformity with the reading of subsumption in the model of predicate calculus: roughly speaking, as an object ' $x$ ' falling under a function ' $\mathrm{F}$ ', described in the expression ' $\mathrm{F}(\mathrm{x})$ '. Beyond the explicit connection to Aristotelian logic, stated in the introduction of $K r V$ (B viii), it seems problematic to assume this interpretation for at least two more reasons: the unrestricted transitivity of subordination must be denied in this approach, and it imposes constraints on immediate inferences of categorical propositions.

One Aristotelian (The Categories V, 3b , 5, In: Aristotle (1962)) basic thesis about predication is that it is a transitive relation in the sense that if $\mathrm{P}$ is predicated of $\mathrm{S}$, then whatever $\mathrm{S}$ is predicated of, $\mathrm{P}$ must also be predicated of. This feature is the first and principal characteristic of the classical theory of predication (Angelelli, 2004). On the other hand, subordination in contemporary logic cannot be transitive, and its understanding of predication differs from this scheme. Indeed, it distinguishes between subsumption, an object falling under a concept, and a concept falling under a concept of a higher order, and none of these relations can be transitive. The second reason is that this interpretation of subordination marks a difference among the ranges of valid inferences: in classical Aristotelian logic, the immediate

predicative judgments, but, on the other hand, flirts with analytical perspective, when explaining disjunctive and hypothetical judgments as having essentially truth-functional form.

Manuscrito - Rev. Int. Fil. Campinas, v. 44, n. 1, pp. 131-148, Jan.-Mar. 2021. 
inference from universal categorical propositions to particulars of the same quality is possible for all terms (e.g., All S is P implies Some $\mathrm{S}$ is $\mathrm{P}$ ). However, in the interpretation from predicate calculus, this inference is blocked in the cases where $\mathrm{S}$ does not refer (e.g., when $\mathrm{S}$ is a 'unicorn', it is not a good inference from $\mathrm{Vx}(\mathrm{Sx} \rightarrow \mathrm{Px})$ to $\exists \mathrm{x}(\mathrm{Sx} \wedge \mathrm{Px}))$. Church (1965) addresses this point and reveals an existential commitment in the modern account that is absent from the ancient scheme.

On the other hand, the interpretation from Port-Royal approaches the question by taking judgment to be the ordination of representations, under the scheme of traditional predication ( $\mathrm{S}$ is $\mathrm{P}$ ). In this reading, predication manifests at least three aspects: it is transitive, as explained above; it is a subordination, given that it classifies representations as superior/genus or inferior/species; and it has an intensional and an extensional aspect. Since the Aristotelian Organon (Prior Analytics, I, xxvii, 43a , 25f, (In: Aristotle, 1962, p. 337)), predication has been presented as a relation, such that if $\mathrm{P}$ is a predicate of $\mathrm{S}, \mathrm{P}$ is superior to $\mathrm{S}$, and $\mathrm{S}$ is inferior to $\mathrm{P}$. Taking the hierarchizing further, $\mathrm{P}$ is genus and $\mathrm{S}$ is species, and so it is appropriate to look for the highest genus and the minimal species (species infima). The distinction between intensional and extensional aspects of subordination was introduced only later in history, in the Port-Royal Logic (Arnauld and Nicole, 1992), where it is presented as "l'éntendue" (extension) and "la compréhension" (comprehension) of universal ideas. The extension refers to the subjects to which an idea applies, which are its inferiors, in relation to which the idea is superior (e.g. the idea of a triangle that has in its extension all the different species of triangles). The comprehension refers to those attributes that an idea involves in itself, e.g. the idea of triangle includes the ideas of figure, three lines, three angles, etc. (Arnauld and Nicole, 1992, p. 51-53). 
Next, the authors (Ibid.) propose that restriction of comprehension destroys the idea, while extension can be restricted in two different ways. An idea can have its extension restricted by the union (joignant) with another distinct idea, for instance, the union of the general idea of triangle with having a right angle, and so lead to the idea of triangle rectangle. The second way to restrict the extension is by adding an indistinct, undetermined idea of some (partie), which recalls what Kant called the form of particular judgment. The 'destruction' of an idea by restriction of its comprehension is not quite clear, but it expresses (in a context where the logic is chiefly psychological, but not subjective) the understanding that concepts can have an empty extension but cannot have an empty comprehension. ${ }^{5}$

Later, Leibniz gave a formulation to this distinction that sounds more like the formulation of the law of inverse reciprocity between intension and extension found in Kant's lectures on logic. In the New Essays (Leibniz, 1900, p. 523), Theophilus states that, in the judgment 'All man is animal',

\footnotetext{
${ }^{5}$ It is reasonable to suppose that even "le supreme de tous les generes", the supreme genus, explained as a genus that cannot be a species, may have some mark in it, although not over it. At the other end of the hierarchy, according to La Logique (Arnauld and Nicole, 1992, p.53) there are ideas that cannot be genus, the 'singular ideas' that are the minimal species ("espèce dernière" or "species infima").

${ }^{6}$ In the original French: 'tout home est animal'. To preserve a link with the Aristotelian tradition, here and henceforth the singular form will be maintained in categorical propositions. As Ian Wilks notes, "[w] hile it is comfortable and intuitive to an English speaker to pluralize both subject and predicate terms in a proposition like 'All men are animals', the practice initiated by Aristotle and transmitted by Boethius is to formulate the proposition with both terms in the singular: 'All man is animal' (Omnis homo est animal). This way of speaking can be taken quite literally as representing the content of the proposition". (WILKS, 2008, p. 85).
} 
"animal includes more individuals than man, but man includes more ideas or more formalities; the one has more examples, the other more degrees of reality; the one more extension, the other more intension. ${ }^{7}$ (NE, IV, xvii, 8)

In turn, Jäsche's text formulates it as "the content (Inhalt) and extension (Umfang) stand in inverse relation to one another. The more a concept contains under itself (unter sich enthält), namely, the less it contains in itself (in sich enthält), and conversely."' (Log, AA 09:95.31-33) These two aspects, content (Inbalt) and extension (Umfang), and their inverse relation appear internalized in Kantian sources and lectures?.

Although the reading from Port-Royal fits chronologically with and finds connections within the Kantian texts, we still have a serious question, which is about the predication of a universal to a singular. In order to establish it, let us take as an example the discussion about the distinction between the analytic and synthetic judgments from Allison (2004, p. 92) and Longuenesse (2000, p. 86f, and p. 107). According to Allison, it is in judgment, and by means of judgment, that concepts are applied "to given data", and he uses the

7 "L'animal comprend plus d'individus que l'homme, mais l'homme comprend plus d'idées ou plus de formalités ; l'un a plus d'exemples, l'autre plus de degrés de réalité ; l'un a plus d'extension, l'autre plus d'intension." (NE, IV, xvii, 8)

8 "Inhalt und Umfang eines Begriffes stehen gegen einander in umgekehrten Verhältnisse. Ie mehr nämlich ein Begriff unter sich enthält, desto weniger enthält er in sich und um gelehrt." (Log., $\$ 7$ AA, 09:95.31-33)

${ }^{9}$ The distinction between content (intension) and extension is in: Meier's book (Auszug aus der Vernunftlehre, 1752 - AA 26:559-567) - Kant's manual for lectures on logic, and in the transcription of his classes, such as in Blomberg Logic (1770s - V-Lo/Blomberg, AA 24:258), Vienna Logic (1780s - V-Lo/Wiener, AA 24:908f.), and in Dohna-Wundlacken Logic (1792 - V-Lo/Dohna, AA 24:488).

Manuscrito - Rev. Int. Fil. Campinas, v. 44, n. 1, pp. 131-148, Jan.-Mar. 2021. 
distinction between intension and extension to overcome the problem of logical and phenomenological explanation of analytic and synthetic judgments. He proposes that, for Kant, an analytic judgment

rests upon his conception of a concept as a set of marks (themselves concepts), which are thought together in an 'analytic unity' [...]. These marks collectively constitute the intension of a concept. One concept is contained in another, just in case it is either a mark of the concept or a mark of one of its marks. [...] thus, unlike most contemporary conceptions of analyticity, Kant's is thoroughly intensional. (Allison, 2004, p. 92)

On the other hand, synthetic judgments are associated with the extensional relation, where scholars take singular representations (intuitions) to also be included. Referring to Logic (Log, AA 09:111.1-14), Allison (2004, p. 92) finds the ' $\mathrm{x}$ ' that grounds the synthesis of judgment in intuition. Based on the same text of Logic, Longuenesse (2000, p. 86) proposes a conception of judgment as "extensional subordination of concepts". She states, "what ultimately makes the combination of concepts possible is always their relation to an ' $x$ ' of judgment." (Longuenesse, 2000, p. 87). In addition she affirms that "Kant then specifies that two concepts a and $b$ can be said to belong to the same $x$ in two ways: either $b$ is already contained in concept $a$, (...) or $b$ belongs to the $x$ thought under $a$, without being contained in a" (Longuenesse, 2000, p. 107). Her suggestion is that a judgment is analytic if it can be solved without resorting to the ' $x$ ' (the intuition under the extension of concepts) and synthetic if otherwise. What she wants to emphasise is "the place of sensible intuition right in the logical form of judgment itself, by means of the term ' $x$ ' - a sensible intuition that 
provides the cement holding concepts together" (idem, ibidem). Though she denies the association of Kant's conception of extension with the contemporary Russellian notion of the class of individuals, she proposes that "the extension of a concept consists of representations thought under it, whether these representations are universal or singular." (Longuenesse, 2000, p. 383, and note 97).

Although this may be a good interpretation of Port-Royal Logic's conception of extension, which admits a species that cannot be a genus, the "espèce dernière" or "species infima" (Arnauld and Nicole, op. cit. p. 53), it is not a good interpretation of Kant's conception. First, this is because the text states that logic abstracts from all content of knowledge ( $\mathrm{rr} V \mathrm{~A} 54 / \mathrm{B} 78)$, and the content of knowledge is given in intuition ( $K r V$ A92/B125), which is singular and refers immediately to objects (KrV A320/B376-7.). Thus, general logic must abstract from all intuition - even transcendental logic only deals with pure thought of an object $(\mathrm{KrV}$ A55/B79-80) - and represents it from mere understanding (Log, AA, 09:16.4-12) - so, the logical form of judgment cannot comprise the predication of a concept to an intuition. Second, the complete distinction between faculties, actions and products (understanding, thinking, and general, discursive and spontaneous representations, but, on the other hand, sensibility, perceiving, and singular, intuitive and passive representations) indicates that the relation between them cannot be explained only by logical means. Indeed, it is a transcendental question, whose fundamental core is explained in the Transcendental Deduction and the Schematism. Third, according to all this, the assumption of species infima is denied by the text:

Hence every genus requires different species, and these subspecies, and since none of the latter once again is ever without a sphere, (a 
domain as a conceptus communis),' reason demands in its entire extension that no species be regarded as in itself the lowest; for since each species is always a concept that contains within itself only what is common to different things, this concept cannot be thoroughly determined, hence it cannot be related to an individual, consequently, it must at every time contain other concepts, i.e., subspecies, under itself. ${ }^{10} \quad(K r V, \quad$ A655-6/B683-4, emphasis added)

As there cannot be a singular (an intuition) in the extension of concept, judgment cannot even encompass the predication of a concept to an intuition. Keeping these considerations in mind, it seems reasonable to consider judgment as subordination consisting exclusively of universal representations.

The first challenge that this view faces is the objection from singular judgments. Nevertheless, the reduction of the singular form of judgment to the universal is asserted as justified from the merely logical point of view, since, in both forms, the subject is entirely included in the extension of the predicate $(\mathrm{KrV}, \mathrm{A} 71 / \mathrm{B} 96)$. The basis of the association of

10 "Daher jede Gattung verschiedene Arten, diese aber verschiedene Unterarten erfordert; und da keine der letzteren stattfindet, die nicht immer wiederum eine Sphäre (Umfang als conceptus communis) hätte, so verlangt die Vernunft in ihrer ganzen Erweiterung, daß keine Art als die unterste an sich selbst angesehen werde, weil, da sie doch immer ein Begriff ist, der nur das, was verschiedenen Dingen gemein ist, in sich enthält, dieser nicht durchgängig bestimmt, mithin auch nicht zunächst auf ein Individuum bezogen sein könne, folglich jederzeit andere Begriffe, d. i. Unterarten, unter sich enthalten müsse." (KrV, A655-6/B6834, emphasis added) 
singular judgment with the predication of a concept to an intuition seems to be found in Logic. "in the singular judgment, finally, a concept that has no sphere at all is enclosed, merely as part then, under the sphere of another." ${ }^{11}(\log , \mathrm{AA}, 09: 102.16-18)$ Regarding the concept without extension, however, the same text considers that,

For even if we have a concept that we apply immediately to individuals, there can still be specific differences in regard to it, which we either do not note, or which we disregard. Only comparatively for use are there lowest concepts, which have attained this significance, as it were, through convention, insofar as one has agreed not to go deeper here. ${ }^{12}(\log$. AA 09:97.24-29)

Therefore, the concept that does not have a sphere is still a concept. The basic reason for not taking the 'lowest concepts' as individuals is grounded on the distinction between concepts and intuition:

Since only individual things, or individuals, are thoroughly determinate, there can be

11 "im einzelnen Urteile endlich wird ein Begriff, der gar keine Sphäre hat, mithin bloß als Theil unter die Sphäre eines andern beschlossen". (Log, AA, 09:102.16-18)

12 Denn haben wir auch einen Begriff, den wir unmittelbar auf Individuen anwenden: so können in Ansehung desselben doch noch specifische Unterschiede vorhanden sein, die wir entweder nicht bemerken, oder die wir aus der Acht lassen. Nur komparativ für die Gebrauch gibt es niedrigste Begriffe, die gleichsam durch Konvention diese Bedeutung erhalten haben, sofern man übereingekommen ist, hierbei nicht tiefer zu gehen. ( $\log , \mathrm{AA}$, 09:97.24-29) 
thoroughly determinate cognitions only as intuitions, but not as concepts; in regard to the latter, logical determination can never be regarded as completed. ${ }^{13}(\log , \mathrm{AA}, 09: 99.13-$ 16)

Thus, it is reasonable to accept this restriction as a consequence of the distinction in kind (Beiser, 1992, p. 26) between representations (intuitions and concepts) and to assume that even the subject of singular judgments must potentially be a genus.

Now it is time to look into the logical scheme of extensional and intensional relations, in order to understand how subordination can be seen in this scenario. Taking judgment to be subordination only of universal representations (concepts) shows some differences between extensional and intensional subordination. Indeed, these differences help to explain the distinctions between synthetic a posteriori, synthetic a priori and analytic judgments.

From the point of view of extensional subordination, 'S is P' means that the extension of $\mathrm{S}$ is under the extension of $\mathrm{P}$. However, this is not sufficient to determine $\mathrm{P}$ as superior or a genus of $\mathrm{S}$, because the truth of a universal affirmative judgment, 'All S is P', may be consistent with 'All $P$ is $S$ ' and 'Some P is S'; or else, with 'Some P is S' and 'Some P is not $\mathrm{S}$ '. In other words, from the mere standpoint of extension, subordination does not determine the symmetry (i.e., 'All S is P' does not imply 'All P is S') nor the asymmetry (i.e., it

${ }^{13} \mathrm{Da}$ nur einzelne Dinge oder Individuen durchgängig bestimmt sind: so kann es auch nur durchgängig bestimmte Erkenntnisse als Anschauungen, nicht als Begriffe, geben; in Ansehung der letztern kann die logisch Bestimmung nie als vollendet angesehen werden. (Log, AA, 09:99.13-16) 
does not exclude 'All P is S'), so it does not suffice to order concepts in the genus/species hierarchy.

This feature of extensional relation may be better visualised in terms of examples. Let us begin with two true synthetic a priori judgments: 'All Triangle is Trilateral' and 'All Trilateral is Triangle', from which we cannot classify the concepts as genus and species. The same seems to happen with some empirical judgments (synthetic a posteriori), such as 'All Greek is Man' and 'Some Man is Greek'; the first puts Greek under Man and the second a part of Man under Greek. Which is a species or genus is not clear at all.

On the other hand, thanks to the intensional relation, the situation is different. One important thing in order to establish how the inclusion of marks (concepts) must be understood is to pay attention to the distinction between coordinate and subordinate marks in the introduction of Logic. The combination of co-ordinate marks (nach einander) forms the whole of a concept and restricts the extension but, as a mere aggregate, cannot determine which is superior or inferior. Only in subordination (unter einander)

the series of subordinate marks terminates $a$ parte ante, or on the side of the grounds, in concepts which cannot be broken up, which cannot be further analysed on account of their simplicity; a parte post, or in regard to the consequences, it is infinite, because we have a highest genus but no lowest species. ${ }^{14}(\log \mathrm{AA}$ 09:59. 17-21)

14 die Reihe subordinierter Merkmale stößt a parte ante, oder auf Seiten der Gründe, an unauflösliche Begriffe, die sich ihrer Einfachheit wegen nicht weiter zergliedern lassen, a parte post, oder in Ansehung der Folgen hingegen, ist sie unendlich, weil wir zwar

Manuscrito - Rev. Int. Fil. Campinas, v. 44, n. 1, pp. 131-148, Jan.-Mar. 2021. 
The conceptual subordination that establishes the intensional series (unter einander), therefore, structures concepts as superior/inferior or genus/species. Thus, if in the judgment, 'S is P', P is included in S, simultaneously, as a mark and a superior concept (engendering an intensional series), so PS must be a different series from SP. For instance - passing over the difficulty of linguistic expression - the intensional series 'Man Greek' characterizes a different concept of 'Greek Man'. If Man is superior, Greek is a species of Man, aside from others, like Barbarian, and under it, there would also be other possible concepts, like Athenian and Spartan. On the other hand, if Greek is superior to Man (as in 'Some Man is Greek'), the concept is not Greek as a species of Man, but something like 'Greek thing', of which 'Greek Man' is a species, alongside 'Greek jewels', 'Greek ruins', etc.

The subordination of marks that constitutes an intensional series must be asymmetric. That is, if $\mathrm{P}$ is included in $\mathrm{S}, \mathrm{S}$ is not included in $\mathrm{P}$, unless $\mathrm{S}$ and $\mathrm{P}$ stay in the same place in the hierarchy of concepts, as Triangle and Trilateral do. All marks that fit in one fit in another, although 'All Triangle has three angles' is an analytic judgment, and 'All Triangle is Trilateral' is synthetic. When two terms occupy the same position in the intensional series, it leaves open what aspect of the concept will be highlighted in its expression, e.g., 'Triangle': three angles and 'Trilateral': three sides. Two concepts being in the same place in the intensional series is the same as both having in themselves the same marks and under themselves the same species.

As judgment is interpreted as subordination of concepts exclusively, the intensional aspect is important for the

ein höchstes genus, aber keine unterste species haben. (Log, AA, 09:59.17-21) 
structuring into genus and species. When a judgment does not determine the hierarchy, it also does not determine the extensional relation at all. In some analytic, some synthetic $a$ priori, and synthetic a posteriori judgments (e.g. 'All Triangle has three angles', 'All Triangle is Trilateral' and 'All Male has a pair of XY chromosomes'), symmetric inversion is possible. Therefore, they enlarge 'intensive distinction' but do not imply 'extensive restriction', which is indeed an obvious constraint on the law of inverse relation between intension and extension.

Now, returning to the question about the ' $x$ ' that makes subordination in judgment possible, it may be useful to look forward in $K r V$, to the Transcendental doctrine of method (A70894/B736-822), in order to summarise the answer, and see that it has a triple aspect: mathematical, empirical and philosophical knowledge. In geometry, it is the 'ostensive construction' 15 that grounds the universal and necessary inclusion of the mark, 'Trilateral' in the 'Triangle' (as well as the inverse), in a universal, affirmative, categorical, and apodictic judgment: 'All Triangle is Trilateral'. This is a synthetic a priori judgment, and it is synthetic because the predicate, Trilateral, cannot be linked to the concept, Triangle, only by logical means. The knowledge of mathematics is explained by Kant as being grounded in the 'construction' of its concepts on the a priori form of appearances (time and space), from which is derived the apriority of its judgments. Therefore, although there is a universal, necessary relation between angles and sides of triangles, it is not grounded in merely logical analysis, but in the spatial structure of human perception.

Synthetic a posteriori judgments like 'All Man is Biped' include 'Biped' in 'Man' grounded in something different,

15 A comprehensive presentation of the Kantian philosophy of mathematics is found in Section 2 of SHABEL, 2019. 
which is experience. This is a synthetic judgment because the connection between 'Biped' and 'Man' is not necessary, and, as the ' $\mathrm{x}$ ' is a posteriori, it is a universal, affirmative judgment, albeit assertoric. The synthetic a priori judgments of philosophical knowledge must have an a priori grounding too, but not in mathematical construction. A central Kantian thesis is that these judgments guide the constitution of experience, and so they are principles of pure understanding. The Transcendental Analytic pursues proof of these principles, but, unfortunately, this discussion exceeds the scope of this paper.

In conclusion, recalling the main theses, the analysis of the central nucleus of Kant's conception of judgment under exegetical, logical and historical burdens reveals the import of the hierarchical organization of some system of conceptual representations for knowledge. The epistemic import of a judgment relies on the grounding that the understanding uses to depict its conceptual schemes, which are properly organized intensionally. The relation of a singular representation (an intuition) with a concept, or of an object with a concept, is not a logical issue; it is a transcendental matter and depends on other elements revealed in the Transcendental Deduction and the Schematism, just as an unbiased reader would expect. Finally, beyond logical, epistemic import, this conception of judgment helps to elucidate the Metaphysical Deduction and even the Transcendental Deduction, a task that must be reserved for future papers.

\section{References}

KANT I. Gesammelte Schriften Hrsg.: Bd. 1-22 Preussische Akademie der Wissenschaften, Bd. 23 Deutsche Akademie der Wissenschaften zu Berlin, ab Bd. 24 
Akademie der Wissenschaften zu Göttingen. Berlin, $1900 \mathrm{ff}$.

. Critique of pure reason. Ed. e trad. Paul Guyer e Allen W. Wood. The Cambridge edition of the works of Immanuel Kant. Cambridge: Cambridge University Press, 1998.

- The Jäsche Logic. In: YOUNG, Michael (Ed. e Trad.). Lectures on Logic. The Cambridge Edition of the Works of Immanuel Kant. Cambridge: Cambridge Universtity Press, 1992. p. 517-640.

ALLISON H. E. Kant's Transcendental Idealism. Yale University, 2004.

ANGELELLI I. "Predication Theory: Classical and Modern". In Hochberg H. and Mulligan K. (editors.), Relations and predicates. Frankfurt: Ontos Verlag. 2004, p. 55-80.

ARISTOTLE. The Categories. On Interpretation. Prior Analytics. Trans. Cooke and Tredinnick. Cambridge/Massachusetts: Loeb/ Harvard University Press/ London: Heinemann, 1962.

ARNAULD A. and NICOLE P. [1662] La Logique ou L'art de Penser. Paris: Gallimard, 1992.

BEISER, Frederick. "Kant's Intellectual Development: 1746-1781". In: GUYER, Paul. The Cambridge Companion to Kant. 1992, p. 26-61.

BRANDT R. The Table of Judgments: Critique of Pure Reason $A$ 67-76; B 92-101. Atascadero: Ridgeview, 1995.

CHURCH A. "The History of the Question of Existential Import of Categorical Propositions." In: BARHILLEL, Y. Org. Logic, Methodology and Philosophy of Science. Amsterdam: North Holland, 1965, p. 417-24. 
HANNA, Robert, "Kant's Theory of Judgment", The Stanford Encyclopedia of Philosopby (Winter 2018 Edition), Edward N. Zalta (ed.), URL = $<$ https://plato.stanford.edu/archives/win2018/entri es/kant-judgment/ $>$. Acessed in 08/11/2020.

LEIBNIZ G. W. [1765] Nouveaux Essais sur l'Entendement Humain. In: JANET, Paul. OEuvres Philosophiques de Leibniz. v. 1. Paris: Ancienne Librairie Germer Balillière, 1900, p. 13-498.

LEIBNIZ, G. W. New Essays concerning Human Understanding. Trans. Alfred Gideon Langley. London: Macmillan, 1896.

LONGUENESSE B. Kant and the Capacity to Judge. Sensibility and Discursivity in the Transcendental Analytic of the Critique of Pure Reason. Trans. Charles T. Wolfe. Princeton: Princeton University Press, 2000.

PARIENTE J. C. L'analyse du Langage à Port-Royal. Paris: Minuit, 1985.

SCHULTHESS P. Relation und Funktion: eine systematische und entwicklungsgeschichtliche Untersuchung zur theoretischen Philosophie Kants. Berlin: Walter de Gruyter, 1981.

SHABEL, L., Kant's Philosophy of Mathematics, In: The Stanford Encyclopedia of Philosophy (Spring 2016 Edition), Edward N. Zalta (ed.), 2013. $<$ https://plato.stanford.edu/archives/spr2016/entri es/kant-mathematics/>, accessed in June 2019.

STRAWSON P. F. The bounds of sense. London: Routledge, 1999.

WILKS, Ian. "Peter Abelard and His Contemporaries". In: Woods, John and Gabbay, Dov M. (eds.) Handbook of 
the History of Logic. Medieval and Renaissance Logic, v.2, Amsterdam, (2008), pp. 83-156.

$(\mathrm{cc}) \mathrm{BY}$

Manuscrito - Rev. Int. Fil. Campinas, v. 44, n. 1, pp. 131-148, Jan.-Mar. 2021. 